Ann. Biol. anim. Bioch. Biophys., I971, 11 (4), 547-558.

\title{
SPERM FORMATION IN ZINC-DEFICIENT RATS
}

\author{
Department of Obstetrics and Gynecology \\ Vanderbilt University School of Medicine \\ Nashville, Tennessee 33203
}

Marie-Claire ORGEBIN-CRIST, M. FREEMAN and G. H. BARNEY

\section{SUMMARY}

A quantitative histological study of the early changes in the testes of 8 weanling rats fed a zinc-deficient diet (0.5 p.p.m. Zinc) was made. Eight control rats, pair-fed to the deficient rats, received 30 p.p.m. of Zinc. The earliest statistically significant change is the diminution of elongated stage 3 spermatids (Roosen Runge's classification) after 23 days of zinc deficient diet. Since the number of stage 6 round spermatids after $\mathbf{I} 6$ days of diet was not statistically different from the pair-fed control, it indicates that the earliest effect of zinc deficiency on the testis, is an inhibition of the transformation of round spermatids into elongated ones. These results are discussed in relation to the possible role of zinc on spermatogenesis.

\section{INTRODUCTION}

Since the work of Fol,is, DAY and McColLum (I94I) and MiLL,AR, FischerR, ELCOATE and MAwSON (1958, 1960) it is known that adult male rats fed a zinc-deficient diet for 7 to 8 weeks display various pathological changes : marked growth retardation, loss of hair, alopecea of the backs and shoulders, skin lesions and marked parakeratosis of the esophagus. In addition both the spermatogenic and endocrine testicular function are severely impaired and the zinc concentration in the testes is reduced. All changes except the testicular atrophy are reversed by replacing zinc in the diet. According to these authors, changes in the testicular endocrine function is not a specific consequence of the zinc-deficiency but is caused by a reduced food intake resulting in inanition whereas testicular atrophy is specifically due to an inadequate supply of zinc. The present report describes the early histologic changes in the testes of zinc-deficient weanling rats, in order to elucidate the genesis of the testicular lesion. 


\section{METHODS}

The I6 animals used in this study were part of a group of 46 rats used to study the genesis of esophageal parakeratosis. The result of this part of the study has been reported separately (Barney, Orgebin-Crist, Macapinlac, ig68).

Sixteen $2 \mathrm{I}$-day old male rats, of the Sprague-Dawley strain that averaged $44.8 \mathrm{~g}$ in weight were divided in 2 groups. The first group of 8 rats was fed a zinc-deficient diet (o.5 p.p.m. zinc) containing in grams per Ioo g : zinc-low casein, ${ }^{1} 20$ (4) ; cottonseed oil, ${ }^{2}$ ro ; vitamin-sucrose mix, ${ }^{3} 5$; mineral $\mathrm{mix}^{4} 3.55$; choline chloride, 0.15 ; and sucrose, ${ }^{5} 6 \mathrm{r} .3$; a second pair-fed group of 8 animals was offered the same diet supplemented with $\mathrm{ZnSO}_{4} \cdot 7 \mathrm{H}_{2} \mathrm{O}$ to provide an additional 30 p.p.m. of zinc. All animals were housed in plastic cages designed and made locally ${ }^{6}$. Diet was fed in plastic cups and deionized water was provided ad libitum from plastic bottles. Starting on the sixth day, the daily food intake of the pair-fed group was adjusted to equal the mean intakes of the animals fed the zinc-deficient diet. One testis from 2 zinc-deficient animals and 2 pair-fed controls killed on days 9, I6 and 23 of the experiment was examined histologically, and the other testis was removed for zinc analysis. On day 30,2 zinc-deficient rat were repleted with I $\mathrm{mg}$ of zinc $\left(\mathrm{ZnSO}_{4} \cdot 7 \mathrm{H}_{2} \mathrm{O}\right)$ by intraperitoneal injection after hemicastration. They were fed the control diet for $\mathrm{I}_{4}$ days before removal of the other testis One of the zinc-deficient rats died and results are not included.

The esophagi for light and phase microscopy were fixed in ro p. roo neutral formalin. Testes were fixed in Bouin's fluid, embedded in Paraplast and cut into $7 \mu$ sections. Zinc was determined in testes by atomic absorption spectroscopy. Testes were prepared for analyses by a wet-ashing procedure?.

In each animal the early primary spermatocytes, the old primary spermatocyte and the elongated spermatids were enumerated in 120 cross sections of seminiferous tubules showing the cellular association of stage 3 (Roosen-Runge's classification, Roosen-Runge and GIESEL, 1950). The Sertoli cells with the nucleolus in the plane of the section, the round and the elongated spermatids were enumerated in 60 cross sections of tubules in stage 6 . The counts were averaged per animal and per group and expressed as the number of cells per tubular cross section. To take into account the difference in nuclear diameter Abercrombie's formula was applied. (ABERCROMBIE, I946).

$$
\mathrm{TC}: \mathrm{CC} \times \frac{\mathrm{S}}{\mathrm{S}+d}
$$

$\mathrm{TC}=$ true count, $\mathrm{CC}=$ crude count, $\mathrm{S}=$ section thickness and $d=$ nuclear diameter. In order to adjust the germ cell count for shrinkage of the seminiferous table the Sertoli cell correction factor proposed by CLERMONT and MORGENTHALER, (1955) was used when the number of Sertoli cells with the nucleolus in the plane of the section was significantly different between the control and zinc-deficient group.

\section{RESULTS}

Body weights and testicular zinc concentration at the time of sacrifice are indicated in table $\mathrm{I}$. Zinc concentrations in the testis are variable, but the average concentration in the zinc-deficient group is statistically different from the pair-fed control.

(1) ${ }^{1}$ Case in purified ; Nutritional Biochemicals Corporation, Cleveland. ${ }^{2}$ Vitamin A, I ooo IU (Aquasol A, U. S. Vitamin and Pharmaceutical Corporation, New York), vitamin $D_{2}$, I25 IU (Drisdol, Winthrop Laboratories, New York), and $a$-tocopherol, $60 \mathrm{mg}$ (Nutritional Biochemicals Corporation) were added to ro $\mathrm{g}$ cottonseed oil (Wesson Oil, Hunt-Wesson Foods, Fullerton, California). 'Vitamin-sucrose Mix, $\mathrm{mg} / \mathrm{kg}$ of mix : thiamine $\cdot \mathrm{HCl}, 200$; riboflavin. 120 pyridoxine $\mathrm{HCl}, 80 ; \mathrm{Ca}$ pantothenate, $320 ;$ biotin, 4 ; nicotinic acid, 300 ; folic acid, Io ; vitamin $\mathrm{B}_{12}, 0.40$ : menadione, 6.6; and sucrose to make $\mathrm{r}$ ooo g. ${ }^{4} \mathrm{Each}$ $3.55 \mathrm{~g}$ of mineral mix contained : $(\mathrm{g}) \mathrm{CaHPO}_{4}, 2.58 ; \mathrm{KCl}, 0.343 ; \mathrm{Na}_{2} \mathrm{CO}_{8}$, o.x I $5 ; \mathrm{MgSO}_{4} \cdot 7 \mathrm{H}_{2} \mathrm{O}, 0.405 ;$ $\mathrm{FeSO}_{4} \cdot 7 \mathrm{H}_{2} \mathrm{O}, 0.06$; $\mathrm{MnSO}_{4} \cdot \mathrm{H}_{2} \mathrm{O}$, 0.03I; $\mathrm{CoCI}_{2} \cdot 6 \mathrm{H}_{2} \mathrm{O}$, 0.004 ; $\mathrm{CuSO}_{4} \cdot 6 \mathrm{H}_{2} \mathrm{O}$, o.006; K I, 0.0004 ; and $\mathrm{NaF}$, o.0oo 8. 'Commercial cane suggar. Godchauz Sugar Refining Company, New Orleans, Louisiana. 'Economy Plastics, Nashville, Tennessee. 'Analytical Methods for Atomic Absorption Spectrophotometer Manual 990-9461, I964 Perkin-Elmer Corporation, Norwall, Connecticut. 


\section{TABLE I}

Comparison of body weights, testis weight, seminiferous tubule diameter, testis zinc concentration and incidence of esophageal parakeratosis in pair fed rats and rats fed a zinc-deficient diet

Poids du corps, poids des testicules, diamètre des tubules séminifères, concentration en zinc des testicules et incidence de la parakeratose oesophagienne chez les rats témoins et les rats carencés en zinc

\begin{tabular}{|c|c|c|c|c|c|c|}
\hline \multicolumn{2}{|c|}{$\begin{array}{l}\text { Days - } \\
\text { fed } \\
\text { diet }\end{array}$} & \multirow[t]{2}{*}{$\begin{array}{l}\text { Mean body } \\
\text { wt. when killed } \\
\text { (g) }\end{array}$} & \multirow[t]{2}{*}{$\begin{array}{l}\text { Testes wt. } \\
\text { (mg) }\end{array}$} & \multirow[t]{2}{*}{$\begin{array}{c}\text { Seminiferous } \\
\text { tubule } \\
\text { diameter }\end{array}$} & \multirow[t]{2}{*}{$\begin{array}{c}\text { Testis } \mathrm{Zn} \\
\text { concentration } \\
\text { (mg } \mathrm{Zn} / \mathrm{g} \text { ) }\end{array}$} & \multirow[t]{2}{*}{$\begin{array}{c}\text { Parakeratosis } \\
\text { of } \\
\text { Esophagus }\end{array}$} \\
\hline & & & & & & \\
\hline 9 & $\begin{array}{l}1 \\
2\end{array}$ & $\begin{array}{l}67.5 \\
64.5\end{array}$ & $\begin{array}{l}.457 \\
.417\end{array}$ & $\begin{array}{l}191.5 \\
172.8\end{array}$ & $\begin{array}{r}13.57 \\
9.69\end{array}$ & $\begin{array}{l}\text { no } \\
\text { no }\end{array}$ \\
\hline 16 & $\begin{array}{l}1 \\
2\end{array}$ & $\begin{array}{l}55.8 \\
68.3\end{array}$ & $\begin{array}{l}.616 \\
.660\end{array}$ & $\begin{array}{l}183.5 \\
206.6\end{array}$ & $\begin{array}{r}12.51 \\
9.53\end{array}$ & $\begin{array}{c}\text { yes } \\
\text { no }\end{array}$ \\
\hline 23 & $\begin{array}{l}1 \\
2\end{array}$ & $\begin{array}{l}71.8 \\
70.4\end{array}$ & $\begin{array}{l}.842 \\
.895\end{array}$ & $\begin{array}{l}207.5 \\
196.1\end{array}$ & $\begin{array}{l}10.98 \\
15.03\end{array}$ & $\begin{array}{l}\text { yes } \\
\text { yes }\end{array}$ \\
\hline 30 & $\begin{array}{l}1 \\
2\end{array}$ & - $^{\mathbf{8}}$ & - & $\begin{array}{l}199.3 \\
176.6\end{array}$ & - & - \\
\hline 44 & $\begin{array}{l}1 \\
2\end{array}$ & $\begin{array}{c}141.5 \\
\text { died }\end{array}$ & - & 224.0 & $\begin{array}{c}\text { - } \\
\text { Average } \\
11.89\end{array}$ & no \\
\hline \multicolumn{7}{|c|}{ Pair fed control } \\
\hline 9 & $\begin{array}{l}1 \\
2\end{array}$ & $\begin{array}{l}61.9 \\
70.3\end{array}$ & $\begin{array}{l}.275 \\
.360\end{array}$ & $\begin{array}{l}155.6 \\
173.2\end{array}$ & $\begin{array}{l}13.88 \\
13.70\end{array}$ & $\begin{array}{l}\text { no } \\
\text { no }\end{array}$ \\
\hline 16 & $\begin{array}{l}1 \\
2\end{array}$ & $\begin{array}{l}82.3 \\
91.7\end{array}$ & $\begin{array}{l}.681 \\
.624\end{array}$ & $\begin{array}{l}206.4 \\
202.4\end{array}$ & $\begin{array}{l}13.31 \\
13.92\end{array}$ & $\begin{array}{l}\text { no } \\
\text { no }\end{array}$ \\
\hline 23 & $\begin{array}{l}1 \\
2\end{array}$ & $\begin{array}{l}84.5 \\
93.8\end{array}$ & $\begin{array}{l}.754 \\
.895\end{array}$ & $\begin{array}{l}209.5 \\
218.2\end{array}$ & $\begin{array}{l}16.43 \\
16.89\end{array}$ & $\begin{array}{l}\text { no } \\
\text { ne }\end{array}$ \\
\hline 30 & $\begin{array}{l}1 \\
2\end{array}$ & $\underline{-a}^{\mathbf{a}}$ & - & $\begin{array}{l}215.2 \\
206.0\end{array}$ & - & \\
\hline 44 & $\begin{array}{l}1 \\
2\end{array}$ & $\begin{array}{l}145.1 \\
155.6\end{array}$ & - & $\begin{array}{l}264.8 \\
253.1\end{array}$ & $\begin{array}{c}\text { - } \\
\text { Average } \\
14.69\end{array}$ & $\begin{array}{l}\text { no } \\
\text { no }\end{array}$ \\
\hline
\end{tabular}

$a:$ On day 30 , rats were not killed, but hemicastrated and then repleted by intraperitoneal injection of $\mathrm{Zn}\left(\mathrm{ZnSO}_{4} \cdot 7 \mathrm{H}_{2} \mathrm{O}\right.$ and fed the control diet ad libitum for 14 days). Consequently, no body weight or testis zinc concentration were available on day 30 . 
Parakeratosis (one of the earliest symptoms of zinc-deficiency MILIAR et al. (I958) was evident in one of the rats after 16 days of diet and in all the rats thereafter. After zinc repletion the esophagus was normal.

After nine days of diet the rats were 30 days old. Round spermatids but no elongated spermatids were present in the control testes. In the testes of the zincdeficient rats the number of germ cells was not significantly different between the control and the zinc-deficient group, the difference in the number of pachytene spermatocyte being at the limit of the significance $(t=0.05)$ (table 2$)$.

\section{TABLE 2}

Number of germ cells per tubular cross section of the nine day zinc deficient rat.

Nombre de cellules germinales par coupe de tube séminifêre chez les rats carencés en zinc depuis 9 jours

\begin{tabular}{|c|c|c|c|c|c|c|}
\hline & \multicolumn{3}{|c|}{ Contral } & \multicolumn{3}{|c|}{ Deficient } \\
\hline & $\begin{array}{c}\text { Cell } \\
\text { Count }\end{array}$ & $\begin{array}{l}\text { Nuclear } \\
\text { Diameter }\end{array}$ & $\begin{array}{l}\text { True } \\
\text { Count }\end{array}$ & $\begin{array}{c}\text { Cell } \\
\text { Count }\end{array}$ & $\begin{array}{l}\text { Nuclear } \\
\text { Diameter }\end{array}$ & $\begin{array}{l}\text { True } \\
\text { Count }\end{array}$ \\
\hline $\begin{array}{c}\text { Leptotene } \\
\text { Spermatocyte }\end{array}$ & $\begin{array}{l}\text { (1) } 86.1 \pm 1.4 \\
\text { (2) } 92.6 \pm 1.6 \\
\text { Av. } 89.4 \pm 1.1^{m}\end{array}$ & $\begin{array}{l}5.57 \\
5.64\end{array}$ & $\begin{array}{l}47.9 \\
51.3 \\
49.6\end{array}$ & $\begin{array}{l}82.2 \pm 1.4 \\
87.8 \pm 1.5 \\
85.5 \pm 1.1\end{array}$ & $\begin{array}{l}5.59 \\
5.56\end{array}$ & $\begin{array}{l}45.7 \\
48.9 \\
47.3\end{array}$ \\
\hline $\begin{array}{c}\text { Pachytene } \\
\text { Spermatocyte }\end{array}$ & $\begin{array}{l}\text { (1) } 79.3 \pm 1.2 \\
\text { (2) } 74.8 \pm 0.3 \\
\text { Av. } 77.0 \pm 1.1^{n}\end{array}$ & $\begin{array}{l}8.84 \\
9.12\end{array}$ & $\begin{array}{l}35.0 \\
32.4 \\
33.7\end{array}$ & $\begin{array}{l}94.7 \pm 1.9 \\
83.9 \pm 1.7 \\
89.3 \pm 1.4\end{array}$ & $\begin{array}{l}8.74 \\
8.68\end{array}$ & $\begin{array}{l}42.1 \\
37.4 \\
39.7\end{array}$ \\
\hline $\begin{array}{c}\text { Stage } 6 \\
\text { Spermatids } \\
\text { (round) }\end{array}$ & - & & & - & & \\
\hline $\begin{array}{c}\text { Stage } 3 \\
\text { Spermatids } \\
\text { (elongated) }\end{array}$ & - & & & - & & \\
\hline $\begin{array}{c}\text { Sertoli } \\
\text { Cells }\end{array}$ & $\begin{array}{ll}\text { (1) } 21.5 \pm 0.3^{a} \\
\text { (2) } 22.7 \pm 0.4 \\
\text { Av. } 22.1 \pm 0.2^{m}\end{array}$ & & & $\begin{array}{l}20.0 \pm 0.4^{a} \\
22.8 \pm 0.3 \\
21.4 \pm 0.2\end{array}$ & & \\
\hline
\end{tabular}

$a=$ non significant (within a group)

$m=$ non significant (control-deficient)

$n=t=0.05$ (control-deficient).

After I6 days of zinc-deficient diet there was no significant difference in germ cells counts between the control and deficient group, the difference in young primary spermatocyte number being at the limit of the significance $(t=0.05)$ (table 3). In both control and zinc-deficient testes elongated spermatids had appeared. One of the zinc-deficient rats showed signs of parakeratosis in the esophagus indicating that the zinc deficiency had already taken place. 
After 23 days of zinc-deficient diet both rats showed signs of esophageal parakeratosis. The overall picture of the testes in both groups was similar. A few degenerate tubules were seen but they were in the same proportion in each group. The number of young primary spermatocytes and round spermatids (stage 6) were not

TABLE 3

Number of germ cells per tubular cross section of the 16 day zinc deficient rat

Nombre de cellules germinales par coupe de tube séminifere chez les rats carencés en zinc depuis 16 jours

\begin{tabular}{|c|c|c|c|c|c|c|c|}
\hline & \multicolumn{4}{|c|}{ Control } & \multicolumn{3}{|c|}{ Deficient } \\
\hline & & $\begin{array}{c}\text { Cell } \\
\text { Count }\end{array}$ & $\begin{array}{l}\text { Nuclear } \\
\text { Diameter }\end{array}$ & $\begin{array}{l}\text { True } \\
\text { Count }\end{array}$ & $\begin{array}{l}\text { Cell } \\
\text { Count }\end{array}$ & $\begin{array}{l}\text { Nuclear } \\
\text { Diameter }\end{array}$ & $\begin{array}{l}\text { True } \\
\text { Count }\end{array}$ \\
\hline $\begin{array}{c}\text { Leptotene } \\
\text { Spermatocyte }\end{array}$ & $\begin{array}{l}(1) \\
(2) \\
\text { Av. }\end{array}$ & $\begin{array}{l}90.3 \pm 0.9 \\
92.9 \pm 1.9 \\
91.6 \pm 0.8^{n}\end{array}$ & $\begin{array}{l}5.85 \\
5.81\end{array}$ & $\begin{array}{l}49.1 \\
50.7 \\
49.9\end{array}$ & $\begin{array}{l}91.1 \pm 1.3 \\
85.2 \pm 2.0 \\
88.1 \pm 0.9\end{array}$ & $\begin{array}{l}6.00 \\
5.96\end{array}$ & $\begin{array}{l}49.0 \\
46.0 \\
47.5\end{array}$ \\
\hline $\begin{array}{c}\text { Pachytene } \\
\text { Spermatocyte }\end{array}$ & $\begin{array}{l}\text { (1) } \\
(2) \\
\text { Av. }\end{array}$ & $\begin{array}{l}91.0 \pm 3.8 \\
97.5 \pm 1.4 \\
94.2 \pm 0.9^{m}\end{array}$ & $\begin{array}{l}9.97 \\
9.78\end{array}$ & $\begin{array}{l}37.5 \\
40.6 \\
39.0\end{array}$ & $\begin{array}{l}98.5 \pm 1.7 \\
91.9 \pm 2.6 \\
95 . ? \pm 1.3\end{array}$ & $\begin{array}{l}9.37 \\
9.37\end{array}$ & $\begin{array}{l}42.0 \\
39.2 \\
40.6\end{array}$ \\
\hline $\begin{array}{c}\text { Stage 6 } \\
\text { Spermatids } \\
\text { (round) }\end{array}$ & $\begin{array}{l}\text { (1) } \\
(2) \\
\text { Av. }\end{array}$ & $\begin{array}{l}220.5 \pm 7.6 \\
239.5 \pm 7.8 \\
230.0 \pm 5.7^{m}\end{array}$ & $\begin{array}{l}6.55 \\
6.48\end{array}$ & $\begin{array}{l}114.2 \\
124.3 \\
119.2\end{array}$ & $\begin{array}{l}251.3 \pm 5.4 \\
224.0 \pm 5.2 \\
237.6 \pm 4.2\end{array}$ & $\begin{array}{l}6.42 \\
6.50\end{array}$ & $\begin{array}{l}130.9 \\
116.0 \\
123.4\end{array}$ \\
\hline $\begin{array}{c}\text { Stage } 3 \\
\text { Spermatids } \\
\text { (elongated) }\end{array}$ & $\begin{array}{c}(1) \\
(2) \\
\text { Av. }\end{array}$ & $\begin{array}{l}57.7 \pm 1.5 \\
48.3 \pm 1.7 \\
53.0 \pm 1.2^{m}\end{array}$ & - & - & $\begin{array}{l}68.2 \pm 2.3 \\
43.3 \pm 1.1 \\
55.7 \pm 1.9\end{array}$ & - & - \\
\hline $\begin{array}{c}\text { Stage } 6 \\
\text { Spermatids } \\
\text { (elongated) }\end{array}$ & $\begin{array}{l}(1) \\
(2) \\
\text { Av. }\end{array}$ & $\begin{array}{l}11.8 \pm 1.1 \\
20.8 \pm 1.5 \\
16.3 \pm 1.0^{m}\end{array}$ & - & - & $\begin{array}{l}22.3 \pm 1.4 \\
14.5 \pm 1.1 \\
18.4 \pm 1.0\end{array}$ & & \\
\hline $\begin{array}{l}\text { Sertoli } \\
\text { Cells }\end{array}$ & Av. & $\begin{array}{l}19.9 \pm 0.2^{a} \\
19.7 \pm 0.3 \\
19.8 \pm 0.2^{m}\end{array}$ & & & $\begin{array}{l}20.5 \pm 0.4^{a} \\
20.8 \pm 0.4 \\
20.6 \pm 0.3\end{array}$ & & \\
\hline
\end{tabular}

$a$ : non significant (within a group); (between control-deficient). $m:$ non significant (between control-deficient) ; $n: t=0,05$

different between the control and experimental group. The number of pachytene spermatocytes and elongated spermatids $(t=0.00 r)$ was significantly different (table 4). This was confirmed by the presence of very few sperm in the lumen of the epididymal canal of the zinc-deficient rats in contrast to the many sperm in the epididymides of the pair-fed control. 
After 30 days of diet the difference in the numbers of young primary spermatocyte and elongated spermatids between the control and experimental group was highly significant $(t=0.001$.) There was no difference in the number of pachytene spermatocytes and round spermatids (table 5). There were a number of tubules which showed a non-specific type of degeneration with pyknotic spheres, exfoliation of cells, and the formation of multi-nucleated spermatids. Only tubules not showing this non-specific type of degenerescence were counted. In the epididymis of 30 and $3 \mathrm{I}$-day old rat, no spermatozoa are present in the lumen of the epididymal

TABLE 4

Number of germ cells per tubular cross section of the 23 day zinc deficient rat

Nombre de cellules germinales par coupe de tube séminifere chez les rats carencés en zinc depuis 23 jours

\begin{tabular}{|c|c|c|c|c|c|c|}
\hline & \multicolumn{3}{|c|}{ Control } & \multicolumn{3}{|c|}{ Deficient } \\
\hline & $\begin{array}{c}\text { Cell } \\
\text { Count }\end{array}$ & $\begin{array}{c}\text { Nuclear } \\
\text { Diameter }\end{array}$ & $\begin{array}{l}\text { True } \\
\text { Count }\end{array}$ & $\begin{array}{c}\text { Cell } \\
\text { Count }\end{array}$ & $\begin{array}{c}\text { Nuclear } \\
\text { Diameter }\end{array}$ & $\begin{array}{c}\text { True } \\
\text { Count }\end{array}$ \\
\hline $\begin{array}{c}\text { Leptotene } \\
\text { Spermatocyte }\end{array}$ & $\begin{array}{ll}\text { (1) } & 82.6 \pm 1.2 \\
\text { (2) } & 85.2 \pm 1.3 \\
\text { Av. } & 83.9 \pm 0.9^{m}\end{array}$ & $\begin{array}{l}5.68 \\
5.89\end{array}$ & $\begin{array}{l}45.5 \\
46.3 \\
45.9\end{array}$ & $\begin{array}{l}79.2 \pm 1.1 \\
88.2 \pm 2.0 \\
83.7 \pm 1.2\end{array}$ & $\begin{array}{l}5.79 \\
6.00\end{array}$ & $\begin{array}{l}43.3 \\
47.4 \\
45.3\end{array}$ \\
\hline $\begin{array}{c}\text { Pachytene } \\
\text { Spermatocyte }\end{array}$ & $\begin{array}{l}\text { (1) } 97.6 \pm 1.5 \\
\text { (2) } 90.8 \pm 1.1 \\
\text { Av. } 94.2 \pm 1.0^{n}\end{array}$ & $\begin{array}{l}9.32 \\
9.47\end{array}$ & $\begin{array}{l}41.8 \\
38.6 \\
40.2\end{array}$ & $\begin{array}{l}83.3 \pm 1.3 \\
95.6 \pm 1.6 \\
89.4 \pm 1.1\end{array}$ & $\begin{array}{l}9.59 \\
9.24\end{array}$ & $\begin{array}{l}35.1 \\
41.2 \\
38.1\end{array}$ \\
\hline $\begin{array}{c}\text { Stage 6 } 6 \\
\text { Spermatids } \\
\text { (round) }\end{array}$ & $\begin{array}{l}\text { (1) } 233.7 \pm 4.2 \\
\text { (2) } 225.2 \pm 6.6 \\
\text { Av. } 229.4 \pm 4.3^{m}\end{array}$ & $\begin{array}{l}6.47 \\
6.54\end{array}$ & $\begin{array}{l}121.3 \\
116.4 \\
118.8\end{array}$ & $\begin{array}{l}256.4 \pm 7.3 \\
227.7 \pm 3.1 \\
242.0 \pm 4.3\end{array}$ & $\begin{array}{l}6.56 \\
6.42\end{array}$ & $\begin{array}{l}132.3 \\
118.6 \\
125.4\end{array}$ \\
\hline $\begin{array}{c}\text { Stage } 3 \\
\text { Spermatids } \\
\text { (elongated) }\end{array}$ & $\begin{array}{l}\text { (1) } 150.7 \pm 3.8 \\
\text { (2) } 160.4 \pm 5.2 \\
\text { Av. } 155.5 \pm 3.4^{\circ}\end{array}$ & - & - & $\begin{array}{l}116.4 \pm 3.2 \\
144.6 \pm 3.9 \\
130.5 \pm 2.8\end{array}$ & - & - \\
\hline $\begin{array}{c}\text { Stage 6 } \\
\text { Spermatids } \\
\text { (elongated) }\end{array}$ & $\begin{array}{lr}\text { (1) } & 102.1 \pm 4.2 \\
\text { (2) } & 84.5 \pm 6.1 \\
\text { Av. } & 93.3 \pm 3.8^{\circ}\end{array}$ & - & - & $\begin{array}{l}70.4 \pm 4.8 \\
53.9 \pm 3.3 \\
62.2 \pm 3.0\end{array}$ & - & - \\
\hline $\begin{array}{l}\text { Sertoli } \\
\text { Cells }\end{array}$ & $\begin{array}{ll}\text { (1) } 19.6 \pm 0.5^{a} \\
\text { (2) } 21.0 \pm 0.7 \\
\text { Av. } 20.3 \pm 0.5^{m}\end{array}$ & & & $\begin{array}{l}19.4 \pm 1.2^{a} \\
21.9 \pm 0.8 \\
20.6 \pm 0.8\end{array}$ & & \\
\hline
\end{tabular}

$a:$ non significant (within a group) ; $m:$ non significant (between control-deficient).

$n: t<0.01$ (between control-deficient) ; $\quad 0: t<0.001$ (between control-deficient).

canal. In the epididymis of the 44 and 5I-day old zinc-deficient rat (on day 23 and 30 ) very few sperm could be seen compared with those of the pair-fed controls which were packed with sperm. 


\section{TABLE 5}

\section{Number of germ cells per tubular cross section} of the 30 day zing deficient rat

Nombre de cellules germinales par coupe de tube séminifère chez les rats carencés en zinc depuis 30 jours.

\begin{tabular}{|c|c|c|c|c|c|c|c|}
\hline & \multicolumn{4}{|c|}{ Control } & \multicolumn{3}{|c|}{ Deficient } \\
\hline & & $\begin{array}{c}\text { Cell } \\
\text { Count }\end{array}$ & $\begin{array}{c}\text { Nuclear } \\
\text { Diameter }\end{array}$ & $\begin{array}{l}\text { True } \\
\text { Count }\end{array}$ & $\begin{array}{c}\text { Cell } \\
\text { Count }\end{array}$ & $\begin{array}{c}\text { Nuclear } \\
\text { Diameter }\end{array}$ & $\begin{array}{l}\text { True } \\
\text { Count }\end{array}$ \\
\hline $\begin{array}{c}\text { Leptotene } \\
\text { Spermatocyte }\end{array}$ & $\begin{array}{l}(1) \\
(2) \\
\text { Av. }\end{array}$ & $\begin{array}{l}81.6 \pm 0.1 \\
81.8 \pm 1.4 \\
81.7 \pm 0.8^{n}\end{array}$ & $\begin{array}{l}5.74 \\
6.00\end{array}$ & $\begin{array}{l}44.8 \\
44.0 \\
44.4\end{array}$ & $\begin{array}{l}80.2 \pm 1.3 \\
65.9 \pm 1.9 \\
73.0 \pm 1.3\end{array}$ & $\begin{array}{l}5.60 \\
5.56\end{array}$ & $\begin{array}{l}44.5 \\
31.2 \\
37.8\end{array}$ \\
\hline $\begin{array}{c}\text { Pachytene } \\
\text { Spermatocyte }\end{array}$ & & $\begin{array}{l}87.1 \pm 1.0 \\
79.7 \pm 1.4 \\
83.4 \pm 0.9^{m}\end{array}$ & $\begin{array}{l}9.31 \\
9.49\end{array}$ & $\begin{array}{l}37.4 \\
33.8 \\
35.6\end{array}$ & $\begin{array}{l}80.7 \pm 1.3 \\
87.2 \pm 2.3 \\
83.9 \pm 1.4\end{array}$ & $\begin{array}{l}9.01 \\
9.15\end{array}$ & $\begin{array}{l}35.3 \\
37.7 \\
36.5\end{array}$ \\
\hline $\begin{array}{c}\text { Stage } 6 \\
\text { Spermatids } \\
\text { (round) }\end{array}$ & $\begin{array}{l}(1) \\
(2) \\
\text { Av. }\end{array}$ & $\begin{array}{l}235.4 \pm 5.5 \\
235.0 \pm 4.1 \\
235.2 \pm 3.5^{m}\end{array}$ & $\begin{array}{l}6.43 \\
6.52\end{array}$ & $\begin{array}{l}122.6 \\
121.4 \\
122.0\end{array}$ & $\begin{array}{l}241.1 \pm 3.5 \\
247.4 \pm 5.8 \\
244.2 \pm 3.3\end{array}$ & $\begin{array}{l}6.34 \\
6.42\end{array}$ & $\begin{array}{l}126.5 \\
129.0 \\
127.7\end{array}$ \\
\hline $\begin{array}{c}\text { Stage } 3 \\
\text { Spermatids } \\
\text { (elongated) }\end{array}$ & $\begin{array}{l}(1) \\
(2) \\
\text { Av. }\end{array}$ & $\begin{array}{l}174.3 \pm 6.1 \\
186.6 \pm 5.4 \\
180.4 \pm 3.0^{n}\end{array}$ & - & & $\begin{array}{l}44.3 \pm 4.1 \\
13.1 \pm 1.6 \\
28.7 \pm 2.6\end{array}$ & - & \\
\hline $\begin{array}{l}\text { Stage } 6 \\
\text { Spermatids } \\
\text { (elongated) }\end{array}$ & $\begin{array}{l}(1) \\
(2) \\
\text { Av. }\end{array}$ & $\begin{array}{l}138.1 \pm 3.7 \\
120.7 \pm 3.9 \\
129.4 \pm 2.8^{\circ}\end{array}$ & & & $\begin{array}{l}69.8 \pm 4.1 \\
38.7 \pm 3.2 \\
54.3 \pm 2.9\end{array}$ & & \\
\hline $\begin{array}{l}\text { Sertolj } \\
\text { Cells }\end{array}$ & $\begin{array}{l}(1) \\
(2) \\
\text { Av. }\end{array}$ & $\begin{array}{l}20.1 \pm 0.5^{a} \\
18.4 \pm 0.7 \\
19.2 \pm 0.4^{m}\end{array}$ & & & $\begin{array}{l}20.2 \pm 0.7 a \\
21.4 \pm 0.6 \\
20.8 \pm 0.5\end{array}$ & & \\
\hline
\end{tabular}

\section{DISCUSSION}

In view of the results reported above, the effect of zinc deficiency in the various phases of the formation of the spermatozoa will be discussed. This will be facilitated by the knowledge of the duration of the seminiferous epithelium cycle and its different stages from the work of CLERMONT, LEBLOND and MEISSIER (I959). It is possible to follow the progression of germ cells at different time-intervals : for example, the leptotene spermatocytes in stage 3 counted on day 9 of the experiment will give rise to pachytene spermatocytes in stage 7 on day 16 , to round spermatids in stage 5 on day 23 and to round spermatids in stage 8 on day 30 . 


\section{Spermatogonial divisions}

In only 2 of 8 zinc-deficient rats the number of young primary spermatocytes was reduced. On day $\mathrm{I} 6$, the difference was at the limit of the statistical significance $(t=0.05)$ and the daughter cells of these preleptotene spermatocytes (pachytene spermatocytes at day 23 and round spermatids at day 30 ) were in same numbers in pair-fed control and zinc deficient rat casting further doubt on the significance of the difference observed at day 16.

In conclusion during the first 30 days of zinc deficient diet and with one possible exception (one rat at day 30) the number of preleptotene spermatocytes are alike in the control and $\mathrm{Zn}$ deficient group and one can assume that the spermatogonial divisions were not affected by the zinc-deficient treatment.

\section{Meiotic prophase}

In only one of 8 zinc-deficient rats the number of pachytene spermatocytes was reduced. This was on day 23 , but the daughter cells of these pachytene spermatocytes (round spermatids at day 30) were in same numbers in the control and zinc-deficient group. The meiotic prophase does not seem to be affected by the zinc deficiency treatment during the first 30 days of the treatment.

\section{Reduction divisions}

There was no difference in the numbers of round spermatids in all the zinc deficient rats indicating that the reduction divisions had taken place normally.

\section{Spermatid elongation}

At day 9 of the experiment no elongated spermatids were present. At day I6 their number was not significantly different between the control and the experimental group : the symptoms of zinc deficiency were just developing. Thereafter, although the number of round spermatids was not different, all the counts of elongated spermatids were significantly different in all the zinc-deficient rats as compared to the pair-fed control rats, demonstrating a severe inhibition of the transformation of the round spermatid into the elongated, one very early in zinc deficiency and in all the rats studied.

Zinc, a characteristic constituent of the male reproductive organs and of semen, plays an important but not fully understood role in reproduction (MANN, I964). In plants and microorganisms zinc has been shown to be involved in nucleic acid and protein metabolism, the earliest biochemical lesion in zinc deficiency being a depression in RNA synthesis, followed by a reduction in production of protein and DNA (WINDer and Deinneny, I959; Schneider and Price, I962; WACKer, I962 ; WINDER and O'HARA, I962 ; WEGNER and ROMANO, I963). In testes of zinc-deficient rats Macapinlac, Pearson, Barney and Darby, (I968), Somers and UnderwooD, (I969), were unable to detect impairment of RNA synthesis but found an increase in protein and RNA catabolism in zinc-deficient testes. During spermatogenesis RNA is progressively lost from the developing germ cell (CASPERSSON, I939 ; 
BRACHET, I947). RNA synthesis stops soon after the second meiotic division in very early spermiogenesis (MONESI, I965). Therefore the most likely cells to be injured during zinc deficiency would be spermatogonia and spermatocytes where both RNA content and RNA synthesis is higher than in the spermatids. Although this may very well occur later in zinc deficiency, the first germ cells affected in our experiment were the spermatids and more specifically the spermatids undergoing the process of elongation.

In this regard, zinc has been shown to be present in high concentrations in sperm (MANN, I945; MAwSON and Fisher, I953), WETTERDALE, (r958) showed that the testis of rats attained maximum ${ }^{65} \mathrm{Zn}$ level about I week following isotope injection. Maximum concentration of ${ }^{85} \mathrm{Zn}$ in both caput and cauda epididymidis appeared approximately 2 and 3 weeks respectively after injection of ${ }^{85} \mathrm{Zn}$, suggesting that the element was incorporated in late spermatids and transported from the testis into the epididymis by the spermatozoa. These observations have been confirmed by others (WAKelex, Moffatt, Crook and Mallard, i960; Millar, Vincent and MAwson, I96I ; GunN, Gould and ANDERson, I963). More recently PARIzEK, BOURSNELL, HAY, BABICKY and TAYL,OR, (rg66), studying the zinc content of the maturing rat testis showed that during the first month of life the zinc concentration remained fairly constant. During the second month of life the concentration of testicular zinc increased considerably. This increase coincides roughly with the time when spermatids are transformed into spermatozoa, and the authors postulated that this increase could well be related to the formation of intracellular zinc-metallo proteins including certain zinc-containing enzymes in spermatozoa.

Indeed we would conclude from the present study that zinc is necessary during this critical period since rats fed a zinc-deficient diet exhibit normal spermatogenesis up to the elongation of spermatids. However, the final phase of spermatogenesis is inhibited in the absence of zinc.

Reçu pour publication en mai 1971.

\section{ACKNOWLEDGMENTS}

The authors would like to thark Dr. A. Means for reading this manuscript. The work was supported by Grant HD-oo673 and Career Award Ky-HD-38, 882 from the National Institute of Health and Human Development, the Population Council and the Ford Foundation.

\section{RÉSUMÉ}

SPERMATOGENÈSE CHEZ DES RATS CARENCÉS EN ZINC

Une étude histologique quantitative des modifications précoces dans les testicules de 8 Rats de $2 I$ jours soumis à un régime carencé en zinc (o,5 p.p.m. de zinc) a été menée. 8 Rats témoins reçoivent 30 p.p.m. de zinc. La modification la plus précoce, statistiquement significative est la 
diminution des spermatides allongées du stade 3 (classification de Roosen-Runge) après 23 jours du régime carencé en zinc.

Comme le nombre de spermatides rondes du stade 6 après $I 6$ jours de régime n'est pas statistiquement différent par rapport aux animaux témoins, il apparaît que le premier effet d'une carence en zinc sur le testicule est l'inhibition de la transformation des spermatides rondes en spermatides allongées. Les résultats sont discutés en fonction d'un rôle possible du zinc sur la spermatogenèse.

\section{REFERENCES}

Follis, R. H., DAY H. G., McCollum E. V., I94I. Histological studies of the tissues of rats fed a diet extremely low in zinc. J. Nutri., 22, 223.

Mrllar M. J., Fischer M. I., Elcoate P. V., Mawson C. A., r958. The effects of dietary zinc deficiency on the reproductive system of male rats. Can. J. Biochem. Physiol., 36, 557.

Millar M. J., Elcoate P. V., Fischer M. I., Mawson C. A., rg6o. Effect of testosterone and gonadotrophin injections on the sex organ development of zinc-deficient male rats. Can. J. Biochem. Physiol., 38, I457.

Barney G. H., Orgebin-CRist M. C., Macapinlac M., I968. Genesis of esophageal parakeratosis and histologic changes in the testes of the zinc-deficient rat and their reversal by zinc repletion. $J$. Nutri., 85, 526.

Roosen-Runge E. C., Giesel L. O., 1950. Quantitative studies on spermatogenesis in the albino rat. Am. J. Anat., 87, 1 .

Aвеrсrombie M., I946. Estimation of nuclear population from microtome sections . Anat. Rec., 94, 238.

Clermont Y., Morgentaler H., I955, Quantitative study of spermatogenesis in the hypophysectomized rat. Endocrinology, 57, 369.

Clermont Y., Leblond C. P., Meissier B., I959. Duree du cycle de l'epithelium seminal du rat. Arch. Anat. Morph. Exper., 48, 37.

MANN T., 1964. The biochemistry of semen and of the male reproductive tract. Methuen, London.

Winder E., Denneny J. M., I959. Effect of iron and zinc on nucleic acid and protein synthesis in Mycobactérium smegmatis. Nature, Lond., 184, 742.

Schneider E., Price C. A., rg62. Decreased ribonucleic acid levels : a possible cause of growth inhibition in zinc deficiency. Biochem. Biophys. Acta, 65, 406.

WACKer W. E. C., I962. Nucleic acids and metals. III. Changes in nucleic acid, protein, and metal content as a consequence of zinc deficiency in Euglena gracilis. Biochemistry, 1, 859 .

Winder F. G., O'HARA C., rg62. Effects of iron deficiency and zinc deficiency on the composition of Mycobactérium smegmatis. Biochem. J., 82, 98 .

Wegener W. S., Romano A. H., 1963. Zinc stimulation of RNA and protein synthesis in Rhizopus nigricans. Science, 142, 1670.

Wegener W. S., Romano A. H., r964. Control of isocitratase formation in Rhizopus nigricans. J. Bacteriol., 87, 156.

Macapinlac M. P., Pearson W. N., Barney G. H., Darby W. J., I968. Protein and nucleic acid metabolism in the testes of zinc-deficient rats. $J . N u t r ., 95,569$.

SOMERS M., UNDERwood E. J., r969. Ribonuciease activity and nucleic acid and protein metabolism in the testes of zinc-deficient rats. Aust. J. Biol. Sci., 22, 1277.

Caspersson T., 1939. Utber Die Rolle Der Desoxyribosenukleinsäure Bei Der Zellteilung. Chromosoma, 1, I47.

Brachet J., 1947. Nucleic Acids in the Cell and the Embryo. Symp. Soc. Exp. Biol., 1, 207. Cambridge University Press.

Monesi V., 1965. Synthetic activities during spermatogenesis in the mouse. Exp. Cell. Res., 39, I97.

MaNN T., r945. Studies on the metabolism of semen. I. General aspects occurrence and distribution of cytochrome, certain enzymes and coenzymes. Biochem. J., 38, 45 $\mathrm{x}$.

Mawson C. A., Fisher M. I. 1953. Zinc and carbonic anhydrase in semen. Biochem. J., 55, 696.

WETtERDALE B., I958. Experimental studies on radioactive zinc in the male reproductive organs of the rat. Acta Radiol., Suppl., 156, I.

Wakeley J. C. N., Moffatr B., Crook A., Mallard J. R., rg6o. The distribution and radiation dosimetry of $\mathrm{Zn}-65$ in the rat. Int. J. Appl. Radiat., 7, 225. 
Millar, M. J., Vincent N. R., Mawson C. A., I961. An Auto radiographic study of the distribution of zinc-65 in rat tissue. J. Histochem. Cytochem., 8, Irr.

Guny S. A., Gould T. C., Anderson W. A. D., 1963. Distribution and movement of zinc in the rat testes. Arch. Pathol., 75, 21.

Parize j J., Boursiell J. C., May M. F., Babicky A, Taylor D. M, r966. Zinc in the maturing rat testis, J. Reprod. Fert., 18, sor. 


\section{PLANCHE I}

Rats témoins à gauche, Rats carencés en zinc à droite. I-2. Tête de l'épididyme après 23 jours

$3-4$. Tête de l'épididyme après 30 jours 5-6. Queue de 1'épididyme après 30 jours.

\section{PLATE I}

Frg. I.

Caput epididymidis of a pair-fed rat after 23 days of treatment

FIG. 2.

Caput epididymidis of a 23 day zinc-deficient rat.

FIG. 4.

Caput epididymidis of a 30 day zinc-deficient rat.

Fig. 5 .

Cauda epididymidis of a 30 day pair-fed rat.

FIG. 6.

Cauda epididymidis of a 30 day zinc-deficient rat. 

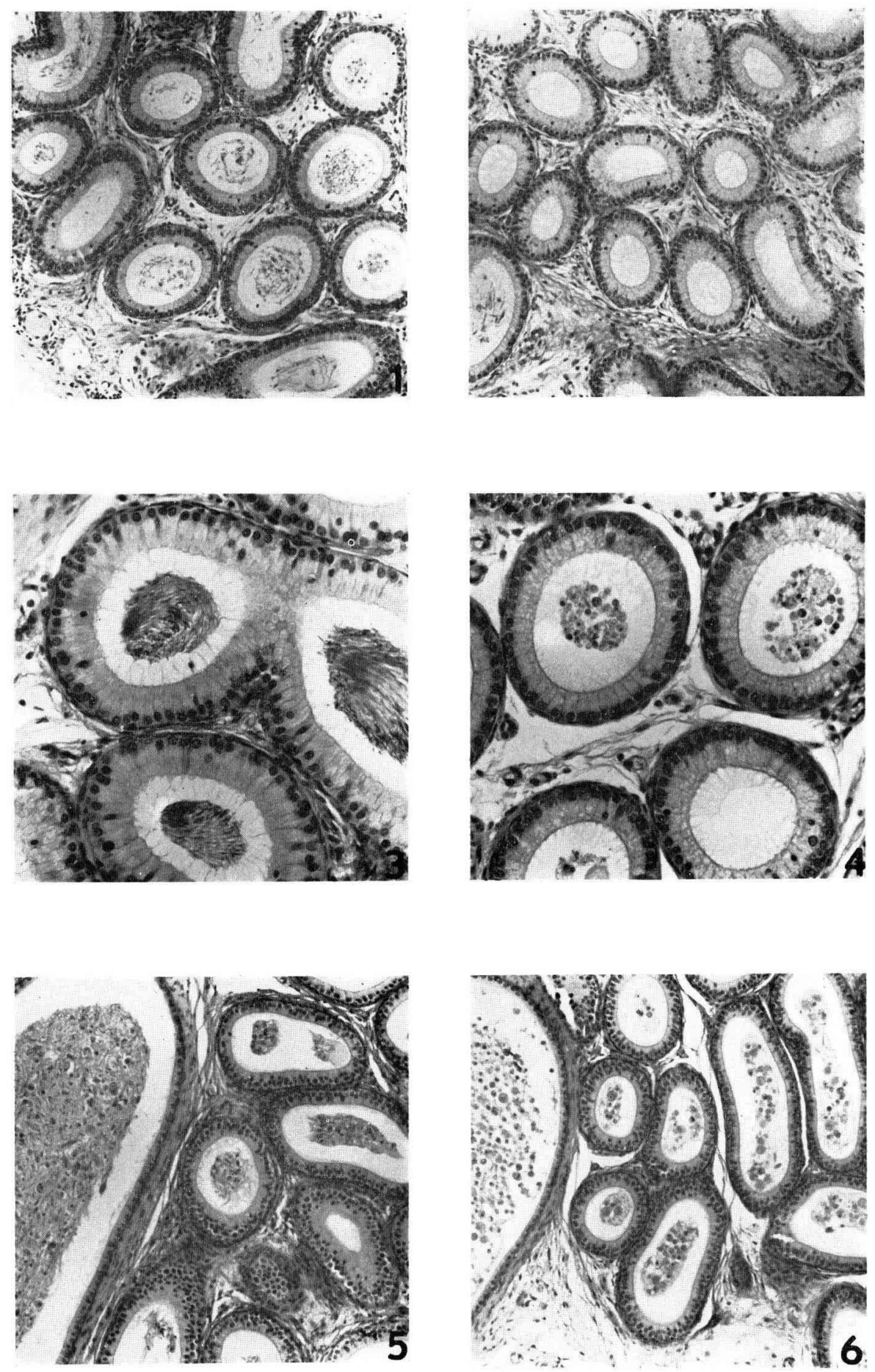

M. C. ORGEBIN-CRIST, M. FREEMAN et G. H. BARNEY 